medRxiv preprint doi: https://doi.org/10.1101/2021.05.28.21258011; this version posted June 25, 2021. The copyright holder for this preprint (which was not certified by peer review) is the author/funder, who has granted medRxiv a license to display the preprint in perpetuity.

It is made available under a CC-BY-NC-ND 4.0 International license .

\title{
Infectious SARS-CoV-2 Virus in Symptomatic COVID-19 Outpatients: Host, Disease, and Viral
}

\section{Correlates}

Katie R. Mollan, MS; Joseph J. Eron, MD; Taylor J. Krajewski, MA; Wendy Painter, MD; Elizabeth R.

Duke, MD; Caryn G. Morse, MD; Erin A. Goecker, MS; Lakshmanane Premkumar, PhD; Cameron R.

Wolfe, MBBS; Laura J. Szewczyk, BS; Paul L. Alabanza, BS; Amy James Loftis, BSc; Emily J. Degli-

Angeli , BS; Ariane J. Brown, BS; Joan A. Dragavon, MLM; John J. Won, BS; Jessica Keys, PhD;

Michael G. Hudgens, PhD; Lei Fang, MS; David A. Wohl, MD; Myron S. Cohen, MD; Ralph S. Baric,

PhD; Robert W. Coombs, MD; Timothy P. Sheahan, PhD*; William A. Fischer II, MD*

*Drs. Sheahan and Fischer contributed equally to this manuscript

Affiliations: Gillings School of Global Public Health, University of North Carolina at Chapel Hill, NC (KRM, JJE, TJK, AJB, JJW, MGH, RSB, TPS); School of Medicine, University of North Carolina at Chapel Hill, NC (KRM, JJE, LP, AJL, DAW, WAF); Center for AIDS Research, University of North Carolina at Chapel Hill, NC (KRM, JJE, TJK, PLA, JK, MGH); Ridgeback Biotherapeutics LP, Miami, Florida (WP, LJS); Fred Hutchinson Cancer Research Center, Seattle, WA (ERD); Wake Forest School of Medicine, Winston-Salem, NC (CGM); Department of Laboratory Medicine and Pathology, University of Washington, Seattle, WA (EAG, EJDA, JAD, RWC); Duke University Medical Center, Durham, NC (CRW); Pharstat Inc., Raleigh, NC (LF); Division of Pulmonary and Critical Care Medicine, University of North Carolina at Chapel Hill, NC (WAF)

Keywords: COVID-19; infectious virus; outpatient; SARS-CoV-2; serostatus

Key Points (Summary): Among COVID-19 outpatients within 7 days of symptom onset, the presence of SARS-CoV-2-specific antibodies was strongly associated with clearance of infectious virus. Seropositivity appears to be more reliable marker of infectious virus clearance than subjective measure of COVID-19 symptoms.

Running title: Infectious SARS-CoV-2 in Outpatients

Page 1 of 35

NOTE: This preprint reports new research that has not been certified by peer review and should not be used to guide clinical practice. 
medRxiv preprint doi: https://doi.org/10.1101/2021.05.28.21258011; this version posted June 25, 2021. The copyright holder for this preprint (which was not certified by peer review) is the author/funder, who has granted medRxiv a license to display the preprint in perpetuity.

\section{It is made available under a CC-BY-NC-ND 4.0 International license .}

\section{Corresponding author:}

Dr. William A. Fischer II: 130 Mason Farm Road, CB\#7020, Chapel Hill, NC 27599

Email: william_fischer@med.unc.edu, Phone: 919-843-9108

\section{Alternate Corresponding author:}

Mrs. Katie R. Mollan: 3126 McGavran-Greenberg Hall, CB\#7420, Chapel Hill, NC 27599

Email: kmollan@unc.edu, Phone: 919-966-8421 
medRxiv preprint doi: https://doi.org/10.1101/2021.05.28.21258011; this version posted June 25, 2021. The copyright holder for this preprint (which was not certified by peer review) is the author/funder, who has granted medRxiv a license to display the preprint in perpetuity.

It is made available under a CC-BY-NC-ND 4.0 International license .

\begin{abstract}
(236/250 words)
Background: While SARS-CoV-2 infectious virus isolation in outpatients with COVID-19 has been associated with viral RNA levels and symptom duration, little is known about the host, disease and viral determinants of infectious virus detection.
\end{abstract}

Methods: COVID-19 adult outpatients were enrolled within 7 days of symptom onset. Clinical symptoms were recorded via patient diary. Nasopharyngeal swabs were collected to quantitate SARS-CoV-2 RNA by reverse transcriptase polymerase chain reaction and for infectious virus isolation in Vero E6-cells. SARS-CoV-2 antibodies were measured in serum using a validated ELISA assay.

Results: Among 204 participants with mild-to-moderate symptomatic COVID19, the median nasopharyngeal viral RNA was 6.5 (IQR 4.7-7.6 $\log _{10}$ copies/mL), and $26 \%$ had detectable SARS-CoV-2 antibodies (IgA, IgM, IgG, and/or total $\mathrm{Ig}$ ) at baseline. Infectious virus was recovered in $7 \%$ of participants with SARS-CoV-2 antibodies compared to $58 \%$ of participants without antibodies (probability ratio $(\mathrm{PR})=0.12,95 \% \mathrm{CI}: 0.04,0.36 ; \mathrm{p}=0.00016)$. Infectious virus isolation was also associated with higher levels of viral RNA (mean RNA difference $+2.6 \log _{10}, 95 \%$ CI: $2.2,3.0$; p<0.0001) and fewer days since symptom onset $(\mathrm{PR}=0.79,95 \% \mathrm{CI}: 0.71,0.88$ per day; $\mathrm{p}<0.0001)$.

Conclusions: The presence of SARS-CoV-2 antibodies is strongly associated with clearance of infectious virus isolation. Seropositivity and viral RNA levels are likely more reliable markers of infectious virus clearance than subjective measure of COVID-19 symptom duration. Virus-targeted treatment and prevention strategies should be administered as early as possible and ideally before seroconversion.

\title{
ClinicalTrials.gov Identifier: NCT04405570
}


medRxiv preprint doi: https://doi.org/10.1101/2021.05.28.21258011; this version posted June 25, 2021. The copyright holder for this preprint (which was not certified by peer review) is the author/funder, who has granted medRxiv a license to display the preprint in perpetuity.

It is made available under a CC-BY-NC-ND 4.0 International license .

\section{Word Count: 2,982 of 3,000}

\section{Introduction}

Severe acute respiratory syndrome coronavirus-2 (SARS-CoV-2), the etiological agent of coronavirus disease-2019 (COVID-19), has caused more than 175 million infections and 3.8 million deaths worldwide. ${ }^{1,2}$ The US Centers for Disease Control and Prevention (CDC) recommends physical isolation of 10 days for individuals with mild-to-moderate COVID-19, and 20 days for individuals with severe disease. ${ }^{3}$ However, infectious SARS-CoV-2 virus isolation has been reported beyond 20 days from patients with a compromised immune system. ${ }^{4-9}$ While prior studies have demonstrated an association between infectious virus isolation in the upper airway and high levels of nasal viral RNA measured by quantitative reverse transcription polymerase chain reaction (qRT-PCR), ${ }^{10-14}$ limited data are available regarding the host and disease factors associated with the presence of infectious virus in persons with mild-to-moderate COVID-19.

An improved understanding of viral and host factors associated with shedding of infectious virus is essential to prevent transmission of SARS-CoV-2 and reliably evaluate the antiviral efficacy of novel therapies. Here, we provide a comprehensive analysis of demographic, immunologic, virologic, and clinical disease factors associated with infectious virus isolation and levels of viral RNA in nasopharyngeal swab samples in the largest study of symptomatic outpatient adults with COVID-19.

\section{Methods}

\section{Study design}

This cross-sectional analysis was conducted at study entry among participants who enrolled in a Phase IIa clinical trial of the oral antiviral agent molnupiravir. Adult outpatients with symptomatic mild-tomoderate COVID-19 in the United States were enrolled within 1 week of symptom onset. ${ }^{15,16}$ The study protocol was approved by Western IRB (WIRB). Ten sites enrolled participants in: North Carolina, California, Washington, Texas, Florida, and Louisiana. All study participants provided written informed 
medRxiv preprint doi: https://doi.org/10.1101/2021.05.28.21258011; this version posted June 25, 2021. The copyright holder for this preprint (which was not certified by peer review) is the author/funder, who has granted medRxiv a license to display the preprint in perpetuity.

It is made available under a CC-BY-NC-ND 4.0 International license .

consent. Participants were eligible to enroll if they were $\geq 18$ years of age, had SARS-CoV-2 infection with symptom onset within the past 7 days (168 hours), and were experiencing symptoms of COVID-19. Active SARS-CoV-2 infection was confirmed by molecular testing from a sample collected within 96hr prior to enrollment. A complete list of eligibility criteria is available at clinicaltrials.gov (NCT04405570).

\section{Measurement of SARS-CoV-2 RNA, Infectious Virus, and Antibodies}

Nasopharyngeal (NP) swabs were collected from each participant at enrollment. Two NP swabs were collected-one from each nostril from all participants except for $n=31$ where a single NP swab was collected and aliquoted for testing. Nasopharyngeal swabs were placed into virus transport medium (VTM; supplied by COPAN), stored at $4^{\circ} \mathrm{C}$ prior to shipping in refrigerated containers to central laboratories, aliquoted, and stored at $-80^{\circ} \mathrm{C}$ until tested. To measure viral RNA, qRT-PCR was performed on NP swabs using CDC primer/probe solution against the N1 region of the nucleocapsid gene (2019nCoV_N1) at Covance CLS with Promega Maxwell for RNA extraction, manual plate build, and Quantstudio 12kflex for the 96 well qRT-PCR format (lower limit of quantification: 1,018 copies $/ \mathrm{mL}) .{ }^{17}$

To measure the presence of infectious virus in each NP swab, samples were cultured in Vero E6 cells similar to prior studies, ${ }^{10}$ and this work was performed in a UNC Department of Environmental Health (EHS)/CDC-approved BSL3 facility following approved standard operating procedures and laboratory safety plans. Briefly, VTM samples were thawed, diluted 1:1 in infection medium and added in duplicate to Vero cell cultures plated $24 \mathrm{hr}$ prior. Quadruplicate negative (infection medium only) high (500 particle forming units, PFU) and low (50 PFU) positive controls were included.(11) On 2 and 5 days post inoculation (dpi), culture positivity was determined by measuring viral RNA in heat-inactivated culture medium by qRT-PCR using the Abbott m2000sp/rt quantitative SARS-CoV-2 RNA assay (limit of quantification: 100 copies/mL). The limit of culture detection was 50 PFU (MOI 0.0008) using two criteria for positivity: (i) SARS-CoV-2 RNA copies $>1,000 / \mathrm{mL}$ in supernatant at 2 dpi, or (ii) a relative change of $>5$ in RNA copy number from 2 to 5 dpi (i.e., [copies_5dpi / copies_2dpi] > 5). 
medRxiv preprint doi: https://doi.org/10.1101/2021.05.28.21258011; this version posted June 25, 2021. The copyright holder for this preprint (which was not certified by peer review) is the author/funder, who has granted medRxiv a license to display the preprint in perpetuity.

It is made available under a CC-BY-NC-ND 4.0 International license .

SARS-CoV-2-specific antibodies in serum were analyzed using an antigen-capture enzyme-linked immunosorbent assay as described previously. ${ }^{18}$ Based on reference panel performance, the following optical density thresholds for seropositivity were applied: total $\operatorname{Ig}>0.376, \operatorname{IgG}>0.376, \operatorname{Ig} \mathrm{A}>0.30$, IgM>0.31. SARS-CoV-2 antibody positive status was determined by a positive result on at least one of the following: total $\mathrm{Ig}, \operatorname{IgG}, \operatorname{IgM}$, or $\operatorname{Ig} \mathrm{A}$.

\section{Covariates}

Participant demographics and disease characteristics were collected at baseline (study entry or screening), including medical history, hematology, and chemistry laboratory tests. Obesity was defined as body mass index $(\mathrm{BMI}) \geq 30 \mathrm{~kg} / \mathrm{m}^{2}$. Days since symptom onset was measured by participant report; and COVID-19 symptom severity was assessed using a four-point scale (absent, mild, moderate, or severe) in the participant-reported diary. Sixteen COVID-related symptoms were collected, as well as overall severity. D-dimer and C-reactive protein (CRP) were measured at local laboratories. D-dimer was dichotomized as $<0.5$ (within or near normal range) versus $\geq 0.5 \mathrm{mg} / \mathrm{L}$, and CRP was dichotomized as $<10$ versus $\geq 10$ $\mathrm{mg} / \mathrm{L}$.

\section{Data analyses}

This analysis includes baseline results from enrolled participants. 95\% confidence intervals (CIs) and pvalues are presented with no adjustment for multiplicity. Missing data were excluded and typically were due to specimen cold-chain shipping abnormalities. Analyses were conducted in Windows SAS version 9.4 (Cary, NC) and Windows R version 4.0.2 or 4.0.4.

Associations between infectious virus isolation and each characteristic were estimated with a probability ratio (PR) and corresponding 95\% CI from a modified Poisson model for bivariate and multivariable analyses. ${ }^{19}$ The following host characteristics were evaluated for associations with infectious virus isolation: presence of antibodies, symptom duration, age, sex, ethnicity (Hispanic versus non-Hispanic), BMI and obesity, frequent medical conditions known to be associated with worse COVID-19 illness 
medRxiv preprint doi: https://doi.org/10.1101/2021.05.28.21258011; this version posted June 25, 2021. The copyright holder for this preprint (which was not certified by peer review) is the author/funder, who has granted medRxiv a license to display the preprint in perpetuity.

It is made available under a CC-BY-NC-ND 4.0 International license .

(diabetes, hypertension, and asthma), overall symptom severity, and five COVID-19 respiratory-related symptoms (cough, shortness of breath, sore throat, nasal obstruction, nasal discharge). Race was not evaluated because few participants self-identified as African-American or Asian. Enrollment of Latinx participants varied considerably by site, and post hoc sensitivity analyses accounting for site were conducted using a Mantel-Haenszel pooled PR. The same statistical approach was used to estimate PRs for associations of each characteristic with seropositive antibody status.

Mean difference in SARS-CoV-2 RNA levels $\left(\log _{10}\right.$ copies/mL) was estimated for each host characteristic listed above using a general linear model with heteroscedasticity-consistent standard errors. A receiver operator curve (ROC) analysis was applied to identify a SARS-CoV-2 RNA cut-point for infectious virus detection that minimized the Euclidean distance between the ROC curve and the $(0,1)$ point in the ROC plane, to maximize sensitivity and specificity. Wilcoxon rank-sum tests were used to compare hematology measures by infectious virus status, and by antibody status. A chi-squared test was used to compare inflammatory markers (D-dimer, CRP) by infectious virus status, and by antibody status.

\section{Results}

\section{Patient Population}

Between 19 June 2020 and 22 January 2021, 240 participants were screened and 204 were enrolled.

Enrollment visits occurred a median of 5 (IQR 4-5) days since symptom onset. Median age was 40 (IQR 27-52) years and 51\% were women. Forty-seven percent of participants were White non-Hispanic, $42 \%$ Hispanic/Latinx, 5\% Black non-Hispanic, 3\% Asian non-Hispanic, and 2\% multiple or other races (Table 1).

Baseline median SARS-CoV-2 viral RNA from NP swabs was 6.5 (IQR 4.7-7.6) $\log _{10}$ copies/mL and 8\% of participants (15/195) had RNA below the limit of quantification (Table 1). Median viral RNA was highest within 3 days after symptom onset (Supplementary Figure 1). Overall symptom severity was rated as mild for $48 \%$, moderate for $45 \%$, and severe for $7 \%$ of participants. The most frequent 
medRxiv preprint doi: https://doi.org/10.1101/2021.05.28.21258011; this version posted June 25, 2021. The copyright holder for this preprint (which was not certified by peer review) is the author/funder, who has granted medRxiv a license to display the preprint in perpetuity.

It is made available under a CC-BY-NC-ND 4.0 International license .

symptoms, regardless of severity, were fatigue (80\%), cough (77\%), stuffy nose (74\%), headache (71\%), and muscle aches (64\%). Loss of smell and taste were each experienced by 54\% of participants (Table 2). Baseline laboratory testing was notable for a median baseline lymphocyte count of $1.4 \times 10^{9} / \mathrm{L}$ (IQR 1.21.9). Most participants had D-dimer and CRP levels within or near the normal range with $80 \%$ below 0.5 $\mathrm{mg} / \mathrm{L}$ and $77 \%$ below $10 \mathrm{mg} / \mathrm{L}$, respectively (Table 1).

\section{SARS-CoV-2 antibodies}

Of 177 patients with evaluable measurements, $26 \%$ were antibody positive at baseline for at least one SARS-CoV-2 spike protein-specific immunoglobulin isotype, with $20 \% \mathrm{IgG}+, 23 \% \mathrm{IgM}+$, and $8 \% \operatorname{IgA}+$ (Table 1). Three participants were $\operatorname{IgG}(+)$ with $\operatorname{IgM}(-)$ and $\operatorname{IgA}(-)$ and one was $\operatorname{IgA}+$ only (Supplementary Table 1). In bivariate analyses, host and disease characteristics associated with having SARS-CoV-2 specific antibodies included longer time since symptom onset (probability ratio [PR]=1.27 per 1 day, 95\%CI: 1.06, 1.52, p=0.0091) and higher white blood cell counts, including total white blood cells and absolute neutrophil count (Supplementary Figure 2). Participants with SARS-CoV-2 antibodies were more likely to have elevated D-dimer and CRP levels as compared to seronegative participants (D-dimer $\geq 0.5 \mathrm{mg} / \mathrm{L}: 39 \%$ versus 13\%, $\mathrm{p}=0.00037$; CRP $\geq 10 \mathrm{mg} / \mathrm{L}: 44 \%$ versus $15 \%$, $\mathrm{p}=0.00011 ;$ Supplementary Table 2).

\section{Correlates of virus isolation}

Infectious virus was isolated from $45 \%$ (78/175) of participants at baseline. Those with positive virus isolation had a median symptom duration of 4 (IQR 3-5) days compared to 5 (IQR 4-6) days in participants with negative virus isolation. Mean viral RNA levels were higher among participants with infectious virus isolation compared to those who were culture negative (mean: 7.6 versus $5.0 \log _{10}$ copies/mL; mean difference: 2.6, 95\%CI: 2.2, 3.0, p<0.0001; Figure 1). An ROC curve analysis revealed that a viral RNA threshold of $\geq 6.4 \log _{10}$ copies $/ \mathrm{mL}$ was predictive of infectious virus isolation 
medRxiv preprint doi: https://doi.org/10.1101/2021.05.28.21258011; this version posted June 25, 2021. The copyright holder for this preprint (which was not certified by peer review) is the author/funder, who has granted medRxiv a license to display the preprint in perpetuity.

It is made available under a CC-BY-NC-ND 4.0 International license .

(Supplementary Figure 3), with an estimated positive predictive value of $80 \%$ and negative predictive value of $91 \%$ (Supplementary Table 3 ).

Infectious virus was isolated from 7\% (3/43) of seropositive compared to 58\% (73/125) of seronegative participants, consistent with an $88 \%$ lower prevalence of infectious virus for those with SARS-CoV-2 antibodies (probability ratio $[\mathrm{PR}]=0.12,95 \% \mathrm{CI}$ : $0.04,0.36, \mathrm{p}=0.00016$ ). Infectious virus was isolated in only three seropositive individuals at 3, 4, and 6 days from symptom onset (all 3 had SARS-CoV-2 specific IgM; 2 had IgG; and 0 had IgA). There was also a strong association between antibody status and NP viral RNA levels (mean: $4.4 \log _{10}$ copies/ml among seropositive versus $6.8 \log _{10}$ copies/ml among seronegative participants; mean difference: -2.4 , 95\%CI: $-2.8,-1.9, \mathrm{p}<0.0001)$. Those with viral RNA levels in the top quartile $\left(>7.6 \log _{10}\right)$ were seronegative $(100 \% ; 43 / 43)$ with the majority $(91 \% ; 39 / 43)$ having infectious virus detected, whereas those in the bottom quartile $\left(<4.7 \log _{10}\right)$ were almost entirely infectious virus negative (98\%; 40/41) and most were seropositive $(68 \% ; 28 / 41)$ (Figure 2).

In a multivariable model (including viral RNA, antibody status, and symptom duration), infectious virus isolation was more prevalent for those with higher viral RNA ( $\mathrm{PR}=1.52$ per $1.0 \log _{10}$ copies $/ \mathrm{mL}, 95 \% \mathrm{CI}$ : $1.37,1.70, \mathrm{p}<0.0001)$ and less prevalent for those with antibodies $(\mathrm{PR}=0.35$ for seropositive versus seronegative, 95\%CI: $0.11,1.07, \mathrm{p}=0.066)$, but was no longer associated with days since symptom onset $(\mathrm{PR}=1.01$ per 1 day, 95\%CI: 0.91, 1.11, $\mathrm{p}=0.90)$.

To evaluate the association between infectious virus isolation and host characteristics both bivariate and multivariable analyses were performed. In bivariate analyses, infectious virus isolation was more prevalent among participants with hypertension ( $\mathrm{PR}=1.62$, 95\%CI: 1.15, 2.28, $\mathrm{p}=0.0054)$ and participants with nasal obstruction ( $\mathrm{PR}=1.53,95 \% \mathrm{CI}$ : 0.97, 2.41, $\mathrm{p}=0.066)$. However, infectious virus isolation was less prevalent among participants who were further from symptom onset $(\mathrm{PR}=0.79$ per 1 day, 95\%CI: $0.71,0.88, \mathrm{p}<0.0001)$, those with moderate-to-severe versus mild symptoms ( $\mathrm{PR}=0.68,95 \% \mathrm{CI}$ : 0.48, 0.96, $\mathrm{p}=0.029)$, those with shortness of breath $(\mathrm{PR}=0.52,95 \% \mathrm{CI}: 0.35,0.77, \mathrm{p}=0.0013)$, and those who self-identified as Latinx compared to non-Latinx ( $\mathrm{PR}=0.54,95 \% \mathrm{CI}$ : $0.36,0.79, \mathrm{p}=0.0016)$. In a sensitivity 
medRxiv preprint doi: https://doi.org/10.1101/2021.05.28.21258011; this version posted June 25, 2021. The copyright holder for this preprint (which was not certified by peer review) is the author/funder, who has granted medRxiv a license to display the preprint in perpetuity.

It is made available under a CC-BY-NC-ND 4.0 International license .

analysis adjusting for site, the association between Latinx ethnicity and lower prevalence of virus isolation remained (Mantel-Haenszel PR=0.52, 95\%CI: 0.28, 0.96, $\mathrm{p}=0.032$ ). In this study, infectious virus isolation was not clearly associated with age $(\mathrm{PR}=1.09$ per 10 years, 95\% CI: 0.98, 1.22, $\mathrm{p}=0.10)$ or biological sex (PR=0.85 women vs. men, 95\%CI: 0.61, 1.19, p=0.34) (Figure 3). In a multivariable model including host characteristics (Supplementary Table 4), seronegativity, fewer days since symptom onset, non-Latinx ethnicity, and hypertension remained associated with higher prevalence of infectious virus isolation.

Bivariate associations between infectious virus isolation and inflammatory and hematology markers were also evaluated. Elevated inflammatory markers were numerically less frequent among participants with infectious virus culture positive compared to culture negative (Supplementary Table 2). Participants with positive infectious virus culture had lower levels of white blood cells including total white blood cell count, absolute lymphocyte count, and absolute neutrophil count (Supplementary Figure 4).

\section{Correlates of viral RNA}

Bivariate analyses of host factor associations with viral RNA level are provided in Supplementary

Figure 5. Higher viral RNA was associated with fewer days since symptom onset (mean difference (MD) $-0.5 \log _{10}$ per 1 day, $95 \% \mathrm{CI}$ : $\left.-0.6,-0.3, \mathrm{p}<0.0001\right)$. There was a trend toward higher viral RNA levels in those with mild symptom severity (MD: $-0.5 \log _{10}$ for moderate-to-severe versus mild symptoms, $95 \% \mathrm{CI}$ : -1.0, 0.07, p=0.086), with median viral RNA levels of 6.8 (IQR 4.8-8.1), 6.4 (IQR 4.6-7.3), and 5.7 (IQR 4.6-7.1) $\log _{10}$ copies/mL for participants with mild, moderate, and severe overall symptom severity, respectively. Viral RNA levels were higher on average for those with hypertension (MD: $1.0 \log _{10}$, 95\%CI: $0.3,1.7, \mathrm{p}=0.0036$ ) or nasal discharge (MD: $\left.0.7 \log _{10}, 95 \% \mathrm{CI}: 0.2,1.2, \mathrm{p}=0.0052\right)$. Lower viral RNA levels were observed for those who self-identified as Latinx; however, in a sensitivity model adjusting for site as a covariate, the association between Latinx ethnicity and viral RNA was no longer present (MD: $-0.01 \log _{10}, 95 \% \mathrm{CI}:-0.7,0.7, \mathrm{p}=0.98$ ). Viral RNA was not associated with age (MD: 0.1 
medRxiv preprint doi: https://doi.org/10.1101/2021.05.28.21258011; this version posted June 25, 2021. The copyright holder for this preprint (which was not certified by peer review) is the author/funder, who has granted medRxiv a license to display the preprint in perpetuity. It is made available under a CC-BY-NC-ND 4.0 International license .

$\log _{10}$ per 10 years of age, $\left.95 \% \mathrm{CI}:-0.06,0.3, \mathrm{p}=0.20\right)$ or body mass index (MD: $0.02 \log _{10}$ per $5 \mathrm{~kg} / \mathrm{m}^{2}$, 95\%CI: $-0.2,0.3, \mathrm{p}=0.83)$. There was some evidence of lower levels of viral RNA in women compared to men (MD: $\left.-0.5 \log _{10}, 95 \% \mathrm{CI}:-1.0,0.02, \mathrm{p}=0.057\right)$.

\section{Discussion}

SARS-CoV-2 infectious virus isolation within 1 week of symptom onset was prevalent and strongly associated with both viral RNA levels and the absence of SARS-CoV-2-specific antibodies, suggesting that humoral immunity plays a key role in limiting infectious virus shedding. This observation is supported by studies identifying prolonged viral replication in individuals with immune deficiencies, nearly all of whom had specific deficiencies in B cell function. ${ }^{4-8,20}$ Importantly, the novel association, in this study, of seropositivity with clearance of infectious virus supports recent reports of increased clinical efficacy of monoclonal antibodies in seronegative patients with COVID-19, ${ }^{21}$ and indicates that seropositivity could be a more reliable indicator of time since infection than duration of symptoms and could serve to identify those who would benefit the most from antiviral therapy.

At entry, most individuals in this study had a cough, nasal obstruction, fatigue, or headache; about half reported sore throat or loss of taste/smell; and $41 \%$ reported feeling feverish, having chills, or experiencing shortness of breath. Our study revealed associations between infectious virus isolation and milder symptoms, an absence of shortness of breath, and lower white blood cell populations, consistent with an early stage in the clinical course of infection. Presence of SARS-CoV-2 antibodies was associated with higher white blood cell and neutrophil counts, which is also consistent with these findings. Prior studies report no virus isolation beyond 10 days from symptom onset in outpatients with mild-moderate COVID-19. ${ }^{11,14,22,23}$ In this study, when accounting for both NP RNA level and serologic response, duration of symptoms (up to 7 days) was no longer associated with infectious virus isolation.

Viral RNA was highest soon after symptom onset with a peak in the median levels $\leq 3$ days after symptom onset, and lower levels for those presenting 5 to 7 days after symptom onset. In this study, viral 
medRxiv preprint doi: https://doi.org/10.1101/2021.05.28.21258011; this version posted June 25, 2021. The copyright holder for this preprint (which was not certified by peer review) is the author/funder, who has granted medRxiv a license to display the preprint in perpetuity.

It is made available under a CC-BY-NC-ND 4.0 International license .

RNA in NP swabs of $6.4 \log _{10}$ copies/mL or higher was predictive of infectious virus detection, with a positive predictive value of $80 \%$ and negative predictive value of $91 \%$, supporting prior studies suggesting a threshold of $6 \log _{10}$ copies/mL. ${ }^{10,11,24}$ However, infectious virus was isolated in three individuals with viral RNA below $5.0 \log 10$ copies/mL (minimum: $4.3 \log 10$ copies $/ \mathrm{mL}$ ), all three of whom were antibody negative men at 6 days from symptom onset, suggesting a delayed immune response.

We did not identify associations between several established risk factors for severe COVID-19 -including age, obesity, diabetes or asthma- and infectious virus isolation or higher levels of viral RNA. However, individuals with hypertension did tend to have higher levels of viral RNA and higher prevalence of infectious virus isolation, the mechanism of which remains unclear. Importantly, most outpatients with mild-to-moderate symptoms, even those in higher risk groups, have a relatively low probability of developing severe COVID-19 disease. ${ }^{25-27}$

This study describes novel associations between virologic and immunologic factors and isolation of infectious virus, however there are important limitations to consider. This was a cross-sectional sample of predominantly low risk, symptomatic outpatients, restricting our target population to those with mild-tomoderate COVID-19. The inclusion of only symptomatic participants precludes an assessment of factors associated with infectious virus among asymptomatic individuals. This study enrolled a large number of participants who identified as Latinx, yet there was an under-representation of African-Americans and Asian-Americans compared with the US burden of COVID-19, limiting generalizability. ${ }^{28}$ Further, seropositivity is not synonymous with virus neutralization. Infectious virus was isolated from three seropositive participants, two of whom also had RNA levels above $6.0 \log _{10}$ but neutralization titers were not measured, thereby limiting this analysis to a qualitative assessment of seropositivity rather than antibody function. We also acknowledge that a negative culture does not entirely exclude the presence of infectious virus. The sensitivity of the virus isolation assay is $50 \mathrm{pfu} / \mathrm{ml}$, and thus infectious virus below 
medRxiv preprint doi: https://doi.org/10.1101/2021.05.28.21258011; this version posted June 25, 2021. The copyright holder for this preprint (which was not certified by peer review) is the author/funder, who has granted medRxiv a license to display the preprint in perpetuity.

It is made available under a CC-BY-NC-ND 4.0 International license .

this limit may not be detected. Additionally, variability in swabbing technique can result in false negative cultures.

Nonetheless, the strong associations we observed between antibody status and viral RNA shedding with isolation of infectious virus provide important insight into viral and host factors associated with infectious SARS-CoV-2 virus. Measuring a patient's serostatus and NP RNA level can help clinicians assess the likelihood of infectious virus detection, which can help guide isolation practices, therapy, and clinical follow-up. Longitudinal research is needed to evaluate whether the early detection of SARS-CoV-2 antibodies can predict subsequent infectious virus clearance and whether early viral clearance decreases the likelihood of long-term COVID-19 symptoms. ${ }^{29}$ As SARS-CoV-2 continues to spread globally, improved understanding of host, disease, and viral factors associated with infectious virus isolation is important to inform non-pharmacologic, vaccine, and therapeutic strategies to interrupt transmission and progression of disease.

Acknowledgements: We thank Dr. Sarah Reifeis for data carpentry support, Ms. Ann Marie Weideman for statistical graphics advice, and Covance by Labcorp for data management support and quantification of viral RNA. We sincerely thank all the participants and sites for their dedication and contributions to the study: Valley Clinical Trials (Northridge, CA), University of North Carolina (Chapel Hill, NC), Fred Hutchinson (Seattle, WA), Care United Research (Forney, TX), Benchmark Research (Colton, CA), FOMAT Medical Research (Oxnard, CA), Indago Research \& Health Center (Hiahleah, FL), Wake Forest Baptist Health (Winston-Salem, NC), Duke University (Durham, NC), and NOLA Research Works (New Orleans, LA). Molnupiravir was invented at Drug Innovations at Emory (DRIVE) LLC, a not-for-profit biotechnology company wholly owned by Emory University and is being developed by Merck \& Co., Inc. in a collaboration with Ridgeback Biotherapeutics.

Funding: This work was supported by Merck \& Co., Inc. in collaboration with Ridgeback Biotherapeutics LP. Support was also provided in part by the National Institutes of Health [P30 
medRxiv preprint doi: https://doi.org/10.1101/2021.05.28.21258011; this version posted June 25, 2021. The copyright holder for this preprint (which was not certified by peer review) is the author/funder, who has granted medRxiv a license to display the preprint in perpetuity. It is made available under a CC-BY-NC-ND 4.0 International license .

AI050410, T32 ES007018 to T.J.K., AI-027757 to R.W.C., AI-106701 to R.W.C.], and a generous gift from the Chan Zuckerberg Initiative to RSB.

Declarations of interest: Grants or contracts were awarded to the participating sites from Ridgeback Biotherapeutics LP. KRM, CGM, and RSB have collaborations, unrelated to this study, with Gilead Sciences. JJE receives consulting honoraria outside the current study from Merck, VIR/GSK, and is a DSMB member for Adagio. WP and LJS are employed by Ridgeback Biotherapeutics LP. CGM has collaborations, unrelated to this study, with Roche, Moderna, Johnson \& Johnson, Covis Pharma, and Chimerix. DAW has collaborations (advisory boards, consultancy, research funding), unrelated to this work, with Gilead Sciences. RSB has collaborations, unrelated to this study, with Moderna, Pfizer, Takeda, Eli Lily, and VaxArt. CRW has, unrelated to this study, financial disclosures for DSMB work with Biogen, Janssen, Merck and Atea, consultancy paid by Enzychem Lifesciences, and honoraria paid by Abbott Laboratories. TPS has contracts, unrelated to this work, from ViiV Healthcare and GSK. WAF has research funding from Ridgeback Biotherapeutics LP, participates on adjudication committees for Janssen, Syneos, and provides consultancy to Roche and Merck. All remaining authors have no conflicts of interest.

Author contributions: KRM, JJE, TPS, and WAF led the conceptualization of the analysis and the writing of original manuscript draft. EAG, LP, EJDA, AJB, JAD, JJW, RSB, RWC, and TPS conducted SARS-CoV-2 laboratory assessments. KRM, TJK, JK, and MGH conducted the statistical analyses. Study data were verified by KRM, TJK, WP, LJS, LF, and WAF. KRM, JJE, WP, LJS, RSB, MGH, LF, DAW, RSB, TPS, and WAF contributed to the study design. WP, ERD, CGM, CRW, LJS, PLA, AJL, and WAF oversaw data collection or protocol implementation. All authors reviewed the draft manuscript and approved the final version.

Data sharing statement: Upon approval from the corresponding author and Ridgeback Biotherapeutics, in collaboration with Merck \& Co., de-identified participant level data may be shared given the 
medRxiv preprint doi: https://doi.org/10.1101/2021.05.28.21258011; this version posted June 25, 2021. The copyright holder for this preprint (which was not certified by peer review) is the author/funder, who has granted medRxiv a license to display the preprint in perpetuity. It is made available under a CC-BY-NC-ND 4.0 International license .

investigator who requests the data has approval from an Institutional Review Board, Independent Ethics Committee, or Research Ethics Board, as applicable, and executes a data use/sharing agreement. 
medRxiv preprint doi: https://doi.org/10.1101/2021.05.28.21258011; this version posted June 25, 2021. The copyright holder for this preprint (which was not certified by peer review) is the author/funder, who has granted medRxiv a license to display the preprint in perpetuity.

It is made available under a CC-BY-NC-ND 4.0 International license .

\section{References}

1. Hu B, Guo H, Zhou P, Shi ZL. Characteristics of SARS-CoV-2 and COVID-19. Nat Rev

Microbiol. 2020;(December). doi:10.1038/s41579-020-00459-7

2. World Health Organization. WHO Coronavirus (COVID-19) Dashboard. https://covid19.who.int/. Accessed June 14, 2021.

3. CDC. Interim Guidance on Duration of Isolation and Precautions for Adults with COVID-19. https://www.cdc.gov/coronavirus/2019-ncov/hcp/duration-isolation.html. Accessed April 12, 2021.

4. Aydillo T, Gonzalez-Reiche AS, Aslam S, et al. Shedding of Viable SARS-CoV-2 after Immunosuppressive Therapy for Cancer. N Engl J Med. 2020;383(26):2586-2588. doi:10.1056/NEJMc2031670

5. Avanzato VA, Matson MJ, Seifert SN, et al. Case Study: Prolonged Infectious SARS-CoV-2 Shedding from an Asymptomatic Immunocompromised Individual with Cancer. Cell. 2020;183(7):1901-1912.e9. doi:10.1016/j.cell.2020.10.049

6. Baang JH, Smith C, Mirabelli C, et al. Prolonged Severe Acute Respiratory Syndrome Coronavirus 2 Replication in an Immunocompromised Patient. J Infect Dis. 2021;223(1):23-27. doi:10.1093/infdis/jiaa666

7. Choi B, Choudhary MC, Regan J, et al. Persistence and Evolution of SARS-CoV-2 in an Immunocompromised Host. N Engl J Med. 2020;383(23):2291-2293. doi:10.1056/NEJMc2031364

8. Tarhini H, Recoing A, Bridier-Nahmias A, et al. Long term SARS-CoV-2 infectiousness among three immunocompromised patients: from prolonged viral shedding to SARS-CoV-2 superinfection. J Infect Dis. February 2021. doi:10.1093/infdis/jiab075 
medRxiv preprint doi: https://doi.org/10.1101/2021.05.28.21258011; this version posted June 25, 2021. The copyright holder for this preprint (which was not certified by peer review) is the author/funder, who has granted medRxiv a license to display the preprint in perpetuity.

It is made available under a CC-BY-NC-ND 4.0 International license .

9. Walsh KA, Spillane S, Comber L, et al. The duration of infectiousness of individuals infected with SARS-CoV-2. J Infect. 2020;81(6):847-856. doi:10.1016/j.jinf.2020.10.009

10. Wölfel R, Corman VM, Guggemos W, et al. Virological assessment of hospitalized patients with COVID-2019. Nature. 2020;581(7809):465-469. doi:10.1038/s41586-020-2196-х

11. van Kampen JJA, van de Vijver DAMC, Fraaij PLA, et al. Duration and key determinants of infectious virus shedding in hospitalized patients with coronavirus disease-2019 (COVID-19). Nat Commun. 2021;12(1):8-13. doi:10.1038/s41467-020-20568-4

12. Liu Y, Yan LM, Wan L, et al. Viral dynamics in mild and severe cases of COVID-19. Lancet Infect Dis. 2020;20(6):656-657. doi:10.1016/S1473-3099(20)30232-2

13. Chen J, Qi T, Liu L, et al. Clinical progression of patients with COVID-19 in Shanghai, China. $J$ Infect. 2020;80(5):e1-e6. doi:10.1016/j.jinf.2020.03.004

14. Bullard J, Dust K, Funk D, et al. Predicting infectious severe acute respiratory syndrome coronavirus 2 from diagnostic samples. Clin Infect Dis. 2020;71(10):2663-2666. doi:10.1093/cid/ciaa638

15. Sheahan TP, Sims AC, Zhou S, et al. An orally bioavailable broad-spectrum antiviral inhibits SARS-CoV-2 in human airway epithelial cell cultures and multiple coronaviruses in mice. Sci Transl Med. 2020;12(541). doi:10.1126/scitranslmed.abb5883

16. Painter WP, Holman W, Bush JA, et al. Human Safety, Tolerability, and Pharmacokinetics of Molnupiravir, a Novel Broad-Spectrum Oral Antiviral Agent with Activity Against SARS-CoV-2. Antimicrob Agents Chemother. 2021;(March). doi:10.1128/AAC.02428-20

17. CDC Diagnostic Test for COVID-19. https://www.cdc.gov/coronavirus/2019-ncov/lab/virusrequests.html. Published 2020. Accessed April 12, 2021.

18. Premkumar L, Segovia-Chumbez B, Jadi R, et al. The receptor binding domain of the viral spike 
medRxiv preprint doi: https://doi.org/10.1101/2021.05.28.21258011; this version posted June 25, 2021. The copyright holder for this preprint (which was not certified by peer review) is the author/funder, who has granted medRxiv a license to display the preprint in perpetuity.

It is made available under a CC-BY-NC-ND 4.0 International license .

protein is an immunodominant and highly specific target of antibodies in SARS-CoV-2 patients. Sci Immunol. 2020;5(48):eabc8413. doi:10.1126/sciimmunol.abc8413

19. Zou G. A Modified Poisson Regression Approach to Prospective Studies with Binary Data. Am J Epidemiol. 2004;159(7):702-706. doi:10.1093/aje/kwh090

20. Buckland MS, Galloway JB, Fhogartaigh CN, et al. Treatment of COVID-19 with remdesivir in the absence of humoral immunity: a case report. Nat Commun. 2020;11(1):6385. doi:10.1038/s41467-020-19761-2

21. Horby PW, Mafham M, Peto L, et al. Casirivimab and imdevimab in patients admitted to hospital with COVID-19 (RECOVERY): a randomised, controlled, open-label, platform trial. medRxiv. January 2021:2021.06.15.21258542. doi:10.1101/2021.06.15.21258542

22. Folgueira MD, Luczkowiak J, Lasala F, Pérez-Rivilla A, Delgado R. Prolonged SARS-CoV-2 cell culture replication in respiratory samples from patients with severe COVID-19. Clin Microbiol Infect. February 2021. doi:10.1016/j.cmi.2021.02.014

23. Singanayagam A, Patel M, Charlett A, et al. Duration of infectiousness and correlation with RTPCR cycle threshold values in cases of COVID-19, England, January to May 2020. Euro Surveill. 2020;25(32). doi:10.2807/1560-7917.ES.2020.25.32.2001483

24. Huang CG, Lee KM, Hsiao MJ, et al. Culture-based virus isolation to evaluate potential infectivity of clinical specimens tested for COVID-19. J Clin Microbiol. 2020;58(8):1-8. doi:10.1128/JCM.01068-20

25. Gottlieb RL, Nirula A, Chen P, et al. Effect of bamlanivimab as monotherapy or in combination with etesevimab on viral load in patients with mild to moderate COVID-19: A randomized clinical trial. JAMA - J Am Med Assoc. 2021;325(7):632-644. doi:10.1001/jama.2021.0202

26. Chen P, Nirula A, Heller B, et al. SARS-CoV-2 Neutralizing Antibody LY-CoV555 in Outpatients 
medRxiv preprint doi: https://doi.org/10.1101/2021.05.28.21258011; this version posted June 25, 2021. The copyright holder for this preprint (which was not certified by peer review) is the author/funder, who has granted medRxiv a license to display the preprint in perpetuity. It is made available under a CC-BY-NC-ND 4.0 International license.

with Covid-19. N Engl J Med. 2021;384(3):229-237. doi:10.1056/nejmoa2029849

27. Weinreich DM, Sivapalasingam S, Norton T, et al. REGN-COV2, a Neutralizing Antibody Cocktail, in Outpatients with Covid-19. N Engl J Med. 2021;384(3):238-251.

doi:10.1056/nejmoa2035002

28. Rossen LM, Branum AM, Ahmad FB, Sutton P, Anderson RN. Excess Deaths Associated with COVID-19, by Age and Race and Ethnicity — United States, January 26-October 3, 2020. MMWR Morb Mortal Wkly Rep. 2020;69(42):1522-1527. doi:10.15585/mmwr.mm6942e2

29. Nalbandian A, Sehgal K, Gupta A, et al. Post-acute COVID-19 syndrome. Nat Med. March 2021. doi:10.1038/s41591-021-01283-Z 
medRxiv preprint doi: https://doi.org/10.1101/2021.05.28.21258011; this version posted June 25, 2021. The copyright holder for this preprint (which was not certified by peer review) is the author/funder, who has granted medRxiv a license to display the preprint in perpetuity.

It is made available under a CC-BY-NC-ND 4.0 International license.

Table 1. Baseline characteristics of outpatients with mild-to-moderate COVID-19 $(n=204)$

\begin{tabular}{|c|c|}
\hline Characteristic & Overall \\
\hline \multicolumn{2}{|l|}{ Sex } \\
\hline Female & $104(51 \%)$ \\
\hline Male & $100(49 \%)$ \\
\hline \multicolumn{2}{|l|}{ Age, years } \\
\hline Median (Q1,Q3) & $40(27,52)$ \\
\hline Min, Max & 18,82 \\
\hline \multicolumn{2}{|l|}{ Race-ethnicity $^{\text {a }}$} \\
\hline Hispanic or Latinx, regardless of race & $86 / 203(42 \%)$ \\
\hline Two or more races, non-Hispanic & $3 / 203(1 \%)$ \\
\hline Asian, non-Hispanic & $6 / 203(3 \%)$ \\
\hline Black, non-Hispanic & $11 / 203(5 \%)$ \\
\hline White, non-Hispanic & $96 / 203(47 \%)$ \\
\hline Other, non-Hispanic & $1 / 203(0 \%)$ \\
\hline \multicolumn{2}{|l|}{ Days since COVID-19 symptom onset } \\
\hline Median (Q1,Q3) & $5(4,5)$ \\
\hline Mean (SD) & $4.5(1.4)$ \\
\hline Min, Max & 0,7 \\
\hline \multicolumn{2}{|l|}{ WHO ordinal scale ${ }^{\text {b }}$} \\
\hline Ambulatory, limitation of activities & $151 / 194(78 \%)$ \\
\hline Ambulatory, no limitation of activities & $43 / 194(22 \%)$ \\
\hline \multicolumn{2}{|l|}{ Body mass index ${ }^{\text {a }}, \mathrm{kg} / \mathrm{m}^{2}$} \\
\hline Median (Q1,Q3) & $27(24,31)$ \\
\hline Min, Max & 18,55 \\
\hline Obesity: $\mathrm{BMI} \geq 30$ & $57 / 203(28 \%)$ \\
\hline \multicolumn{2}{|l|}{ Frequent Medical Diagnoses } \\
\hline Hypertension & $28 / 204(14 \%)$ \\
\hline Diabetes & $20 / 204(10 \%)$ \\
\hline Asthma & $19 / 204(9 \%)$ \\
\hline \multicolumn{2}{|l|}{ Smoking/vaping status ${ }^{\text {a,c }}$} \\
\hline Current & $30 / 203(15 \%)$ \\
\hline Former & $34 / 203(17 \%)$ \\
\hline
\end{tabular}


medRxiv preprint doi: https://doi.org/10.1101/2021.05.28.21258011; this version posted June 25, 2021. The copyright holder for this preprint (which was not certified by peer review) is the author/funder, who has granted medRxiv a license to display the preprint in perpetuity.

It is made available under a CC-BY-NC-ND 4.0 International license .

\begin{tabular}{|c|c|}
\hline Characteristic & Overall \\
\hline Never & $139 / 203(68 \%)$ \\
\hline \multicolumn{2}{|l|}{ Viral RNA from NP swab ${ }^{b}, \log _{10}$ copies/mL } \\
\hline Median (Q1,Q3) & $6.51(4.68,7.61)$ \\
\hline Mean (SD) & $6.19(1.84)$ \\
\hline Min, Max & BLQ-9.93 \\
\hline Below limit of quantification $(<1,018$ copies $/ \mathrm{mL})$ & $15 / 195(8 \%)$ \\
\hline \multicolumn{2}{|l|}{ Infectious virus from NP swab ${ }^{b}$} \\
\hline Positive, $\mathrm{PCR}(+)$ & $78 / 175(45 \%)$ \\
\hline Negative, PCR(-) & $97 / 175(55 \%)$ \\
\hline \multicolumn{2}{|l|}{ SARS CoV-2 Antibodies ${ }^{b}$} \\
\hline Seropositive on any: total $\operatorname{Ig}, \operatorname{IgM}, \operatorname{IgG}$, or $\operatorname{Ig} \mathrm{A}$ & $46 / 177(26 \%)$ \\
\hline $\operatorname{IgM}(+)$ & $40 / 177(23 \%)$ \\
\hline $\operatorname{IgG}(+)$ & $36 / 177(20 \%)$ \\
\hline $\operatorname{IgA}(+)$ & $14 / 177(8 \%)$ \\
\hline \multicolumn{2}{|l|}{ D-dimer ${ }^{b}$, mg/L FEU } \\
\hline Median (Q1,Q3) & $0.28(0.20,0.44)$ \\
\hline Min, Max & $0.15,4.43$ \\
\hline$<0.5 \mathrm{mg} / \mathrm{L} \mathrm{FEU}$ (normal) & $146 / 183(80 \%)$ \\
\hline \multicolumn{2}{|l|}{ C-Reactive Protein ${ }^{\text {b }}, \mathrm{mg} / \mathrm{L}$} \\
\hline Median (Q1,Q3) & $3.0(1.0,8.0)$ \\
\hline Min, Max & $0.3,262.0$ \\
\hline$<10$ mg/L (normal) & $147 / 190(77 \%)$ \\
\hline \multicolumn{2}{|l|}{ White blood cell count, $x 10^{9} / \mathrm{L}$} \\
\hline Median (Q1,Q3) & $4.4(3.7,5.6)$ \\
\hline Min, Max & $1.4,18.3$ \\
\hline \multicolumn{2}{|l|}{ Absolute lymphocyte count ${ }^{b}, \times 10^{9} / L$} \\
\hline Median (Q1,Q3) & $1.4(1.2,1.9)$ \\
\hline Min, Max & $0.5,3.6$ \\
\hline \multicolumn{2}{|l|}{ Absolute neutrophil count ${ }^{b}, 1^{9} / \mathrm{L}$} \\
\hline Median (Q1,Q3) & $2.4(1.8,3.3)$ \\
\hline Min, Max & $0.4,16.8$ \\
\hline
\end{tabular}


medRxiv preprint doi: https://doi.org/10.1101/2021.05.28.21258011; this version posted June 25, 2021. The copyright holder for this preprint (which was not certified by peer review) is the author/funder, who has granted medRxiv a license to display the preprint in perpetuity.

It is made available under a CC-BY-NC-ND 4.0 International license.

\begin{tabular}{|c|c|}
\hline Characteristic & Overall \\
\hline \multicolumn{2}{|c|}{ Absolute monocyte count ${ }^{b}$, x $10^{9} / L$} \\
\hline Median (Q1,Q3) & $0.40(0.30,0.50)$ \\
\hline Min, Max & $0.04,1.10$ \\
\hline \multicolumn{2}{|l|}{ Hemoglobin, g/dL } \\
\hline Median (Q1,Q3) & $14.3(13.4,15.3)$ \\
\hline Min, Max & $8.1,17.7$ \\
\hline
\end{tabular}

${ }^{\mathrm{a}} n=1$ missing. ${ }^{\mathrm{b}}$ Missing data: WHO ordinal scale $(n=10)$, viral RNA $(n=9)$, infectious virus $(n=29)$, antibodies $(n=27)$, D-dimer $(n=21)$, C-reactive protein $(n=14)$, absolute lymphocyte count $(n=34)$ absolute neutrophil count $(n=34)$ absolute monocyte count $(n=35) .{ }^{\mathrm{c}}$ Smoking/vaping status is a composite of cigarette, marijuana, vaping, and cigar use.

$\mathrm{BMI}=$ body mass index; $\mathrm{BLQ}=$ below the limit of quantification $; \mathrm{NP}=$ nasopharyngeal; $\mathrm{PCR}=$ Polymerase Chain Reaction; Q1 $=25^{\text {th }}$ percentile; Q3 $=75^{\text {th }}$ percentile; SARS $=$ Severe acute respiratory syndrome; $\mathrm{SD}=$ standard deviation; US = United States; WHO = World Health Organization. 
medRxiv preprint doi: https://doi.org/10.1101/2021.05.28.21258011; this version posted June 25, 2021. The copyright holder for this preprint (which was not certified by peer review) is the author/funder, who has granted medRxiv a license to display the preprint in perpetuity.

It is made available under a CC-BY-NC-ND 4.0 International license .

Table 2. Symptom severity among outpatients with mild-to-moderate COVID-19 ${ }^{\text {a }}$

\begin{tabular}{lcccc}
\hline & \multicolumn{3}{c}{ Severity ${ }^{\mathbf{b}}$, n (row \%) } \\
\cline { 2 - 5 } Symptom type & Any Severity & Mild & Moderate & Severe \\
\hline Respiratory Symptoms $(\boldsymbol{n}=\mathbf{2 0 2})$ & $155(77 \%)$ & $95(47 \%)$ & $48(24 \%)$ & $12(6 \%)$ \\
Cough & $149(74 \%)$ & $84(42 \%)$ & $53(26 \%)$ & $12(6 \%)$ \\
Nasal obstruction (stuffy nose) & $101(50 \%)$ & $69(34 \%)$ & $28(14 \%)$ & $4(2 \%)$ \\
Sore throat & $91(45 \%)$ & $64(32 \%)$ & $22(11 \%)$ & $5(2 \%)$ \\
Nasal discharge (runny nose) & $83(41 \%)$ & $56(28 \%)$ & $22(11 \%)$ & $5(2 \%)$ \\
Shortness of breath & & & & \\
\hline Other Symptoms $(\boldsymbol{n}=202)$ & $162(80 \%)$ & $73(36 \%)$ & $59(29 \%)$ & $30(15 \%)$ \\
Fatigue & $144(71 \%)$ & $70(35 \%)$ & $52(26 \%)$ & $22(11 \%)$ \\
Headache & $130(64 \%)$ & $62(31 \%)$ & $54(27 \%)$ & $14(7 \%)$ \\
Muscle aches & $109(54 \%)$ & $23(11 \%)$ & $34(17 \%)$ & $52(26 \%)$ \\
Loss of smell & $159(54 \%)$ & $28(14 \%)$ & $35(17 \%)$ & $46(23 \%)$ \\
Loss of taste & $83(41 \%)$ & $54(27 \%)$ & $20(10 \%)$ & $9(4 \%)$ \\
Chills & $82(41 \%)$ & $54(27 \%)$ & $22(11 \%)$ & $6(3 \%)$ \\
Feeling feverish & $64(32 \%)$ & $43(21 \%)$ & $18(9 \%)$ & $3(1 \%)$ \\
Diarrhea & $57(28 \%)$ & $34(17 \%)$ & $16(8 \%)$ & $7(3 \%)$ \\
Nausea & $13(6 \%)$ & $1(<1 \%)$ & $1(<1 \%)$ \\
Fainting & & $95(48 \%)$ & $89(45 \%)$ & $13(7 \%)$ \\
Vomiting & & & \\
\hline Overall Symptom Severity $(\boldsymbol{n}=\mathbf{1 9 7})$ & & & \\
\hline
\end{tabular}

${ }^{\text {a }} n=2$ participants were missing a symptom diary, and $n=5$ additional participants did not report Overall Symptom Severity. ${ }^{\mathrm{b}}$ Participants ranked each reported symptom as Absent, Mild, Moderate, or Severe using a symptom diary. The 'Any Severity' column is a sum of Mild, Moderate, or Severe (i.e., regardless of severity level). 
medRxiv preprint doi: https://doi.org/10.1101/2021.05.28.21258011; this version posted June 25, 2021. The copyright holder for this preprint (which was not certified by peer review) is the author/funder, who has granted medRxiv a license to display the preprint in perpetuity.

It is made available under a CC-BY-NC-ND 4.0 International license.

Supplementary Table 1. SARS-CoV-2 specific antibody combinations

\begin{tabular}{cc}
\hline Measure & Events/n (\%) \\
\hline $\operatorname{IgG}(-), \operatorname{IgM}(-), \operatorname{IgA}(-)$ & $133 / 177(75 \%)$ \\
$\operatorname{IgG}(+), \operatorname{IgM}(+), \operatorname{IgA}(-)$ & $20 / 177(11 \%)$ \\
$\operatorname{IgG}(+), \operatorname{IgM}(+), \operatorname{IgA}(+)$ & $13 / 177(7 \%)$ \\
$\operatorname{IgG}(-), \operatorname{IgM}(+), \operatorname{IgA}(-)$ & $7 / 177(4 \%)$ \\
$\mathrm{IgG}(+), \operatorname{IgM}(-), \operatorname{IgA}(-)$ & $3 / 177(2 \%)$ \\
$\mathrm{IgG}(-), \operatorname{IgM}(-), \operatorname{IgA}(+)$ & $1 / 177(1 \%)$ \\
\hline
\end{tabular}

$\mathrm{CoV}=$ coronavirus; $\mathrm{Ig}=$ immunoglobulin; $\mathrm{SARS}=$ Severe acute respiratory syndrome . 
Supplementary Table 2. Associations between SARS-CoV-2 measures and inflammatory markers

\begin{tabular}{|c|c|c|c|c|c|c|c|}
\hline \multirow[b]{2}{*}{ SARS-CoV-2 Measure } & \multirow[b]{2}{*}{ Group } & \multicolumn{2}{|c|}{ D-dimer (mg/L) } & & \multicolumn{2}{|c|}{ C-Reactive Protein (mg/L) } & \multirow[b]{2}{*}{ p-value } \\
\hline & & $\begin{array}{l}\text { Below 0.5 } \\
\text { (normal) }\end{array}$ & $\begin{array}{c}\text { 0.5 or higher } \\
\text { (elevated) }\end{array}$ & p-value ${ }^{a}$ & $\begin{array}{l}\text { Below } 10 \\
\text { (normal) }\end{array}$ & $\begin{array}{c}10 \text { or above } \\
\text { (elevated) }\end{array}$ & \\
\hline \multirow[t]{2}{*}{ Infectious virus } & Culture positive & $58 / 69(84 \%)$ & $11 / 69(16 \%)$ & 0.21 & $59 / 71(83 \%)$ & $12 / 71(17 \%)$ & 0.12 \\
\hline & Culture negative & $66 / 87(76 \%)$ & $21 / 87(24 \%)$ & & $67 / 92(73 \%)$ & $25 / 92(27 \%)$ & \\
\hline \multirow[t]{2}{*}{ Antibodies } & Seropositive & $25 / 41(61 \%)$ & $16 / 41(39 \%)$ & 0.00037 & $24 / 43(56 \%)$ & $19 / 43(44 \%)$ & 0.00011 \\
\hline & Seronegative & $104 / 120(87 \%)$ & $16 / 120(13 \%)$ & & $104 / 123(85 \%)$ & $19 / 123(15 \%)$ & \\
\hline
\end{tabular}

${ }^{a}$ Chi-square p-value

$\mathrm{CoV}=$ coronavirus $; \mathrm{SARS}=$ Severe acute respiratory syndrome. 
Supplementary Table 3. Nasopharyngeal viral RNA threshold for infectious virus isolation

\begin{tabular}{|l|c|c|c|}
\hline \multicolumn{1}{|c|}{ Viral RNA } & \multicolumn{3}{c|}{ Infectious Virus } \\
\hline $\begin{array}{l}\text { No. of participants } \\
\text { Row \% } \\
\text { Column \% }\end{array}$ & Culture Negative & Culture Positive & Total \\
\hline$<\mathbf{6 . 4} \log _{\mathbf{1 0}}$ copies/mL & 77 & 8 & 85 \\
& NPV: $91 \%$ & $9 \%$ & \\
& Sp: $81 \%$ & $10 \%$ & \\
\hline$\geq \mathbf{6 . 4} \log _{\mathbf{1 0}}$ & 18 & 70 & 88 \\
copies/mL & $20 \%$ & PPV: $80 \%$ & \\
& $19 \%$ & Se: $90 \%$ & \\
\hline Total & 95 & 78 & 173 \\
\hline
\end{tabular}

$\mathrm{NPV}=$ negative predictive value PPV = positive predictive value $; \mathrm{Se}=$ sensitivity $; \mathrm{Sp}=$ specificity 
Supplementary Table 4. Multivariable model of host factor associations with infectious SARS-CoV-2 virus isolation $(n=162)^{\text {a }}$

\begin{tabular}{|c|c|c|c|}
\hline Characteristic (Index, Reference) & $\begin{array}{c}\text { Adjusted } \\
\text { Prevalence } \\
\text { Ratio }\end{array}$ & $\begin{array}{c}95 \% \\
\text { Confidence } \\
\text { Interval }\end{array}$ & p-value \\
\hline Antibody positive in Ig, IgG, IgM, or IgA (Positive, Negative) & 0.15 & $(0.05,0.47)$ & 0.0011 \\
\hline Symptom Onset (per 1 day change in days since symptom onset) & 0.86 & $(0.76,0.97)$ & 0.016 \\
\hline Age (per 10 years change) & 1.06 & $(0.95,1.18)$ & 0.32 \\
\hline Sex (Female, Male) & 0.82 & $(0.61,1.11)$ & 0.20 \\
\hline $\begin{array}{l}\text { Ethnicity (Hispanic or Latinx, } \\
\text { Not Hispanic or Latinx) }\end{array}$ & 0.63 & $(0.45,0.90)$ & 0.011 \\
\hline Obese, BMI of 30+ (Yes, No) & 0.83 & $(0.58,1.21)$ & 0.34 \\
\hline Diabetes (Yes, No) & 0.84 & $(0.48,1.45)$ & 0.52 \\
\hline Hypertension (Yes, No) & 1.57 & $(1.13,2.19)$ & 0.0074 \\
\hline Asthma (Yes, No) & 0.96 & $(0.58,1.60)$ & 0.88 \\
\hline Overall Symptom Severity (Moderate-to-severe, Mild) & 0.97 & $(0.70,1.33)$ & 0.85 \\
\hline
\end{tabular}

$\mathrm{BMI}=$ body mass index; $\mathrm{Ig}=$ immunoglobulin.

${ }^{a}$ Host characteristics in the table were included in this multivariable (modified Poisson) model to estimate adjusted prevalence ratios for the outcome of infectious virus isolation (i.e., culture positive). A prevalence ratio per unit change was estimated for each continuous characteristic, with days since symptom onset and age each fit as linear in the log-prevalence of infectious virus isolation. Participants with missing data were excluded. 


\section{Figures}

Figure 1. SARS-CoV-2 viral RNA levels in nasopharyngeal swab by infectious virus status

Nasopharyngeal viral RNA levels measured via qRT-PCR are displayed by infectious virus status, with culture negative in grey $(n=95)$ and culture positive $(n=78)$ in red; each dot represents a participant. Solid lines on the boxplots display the median and 25 th-75th percentile $($ mean $=$ blue dashed line) and the whiskers extend to the extrema (no more than 1.5 times the IQR from the box). LLoQ = lower limit of quantification; SD $=$ standard deviation.

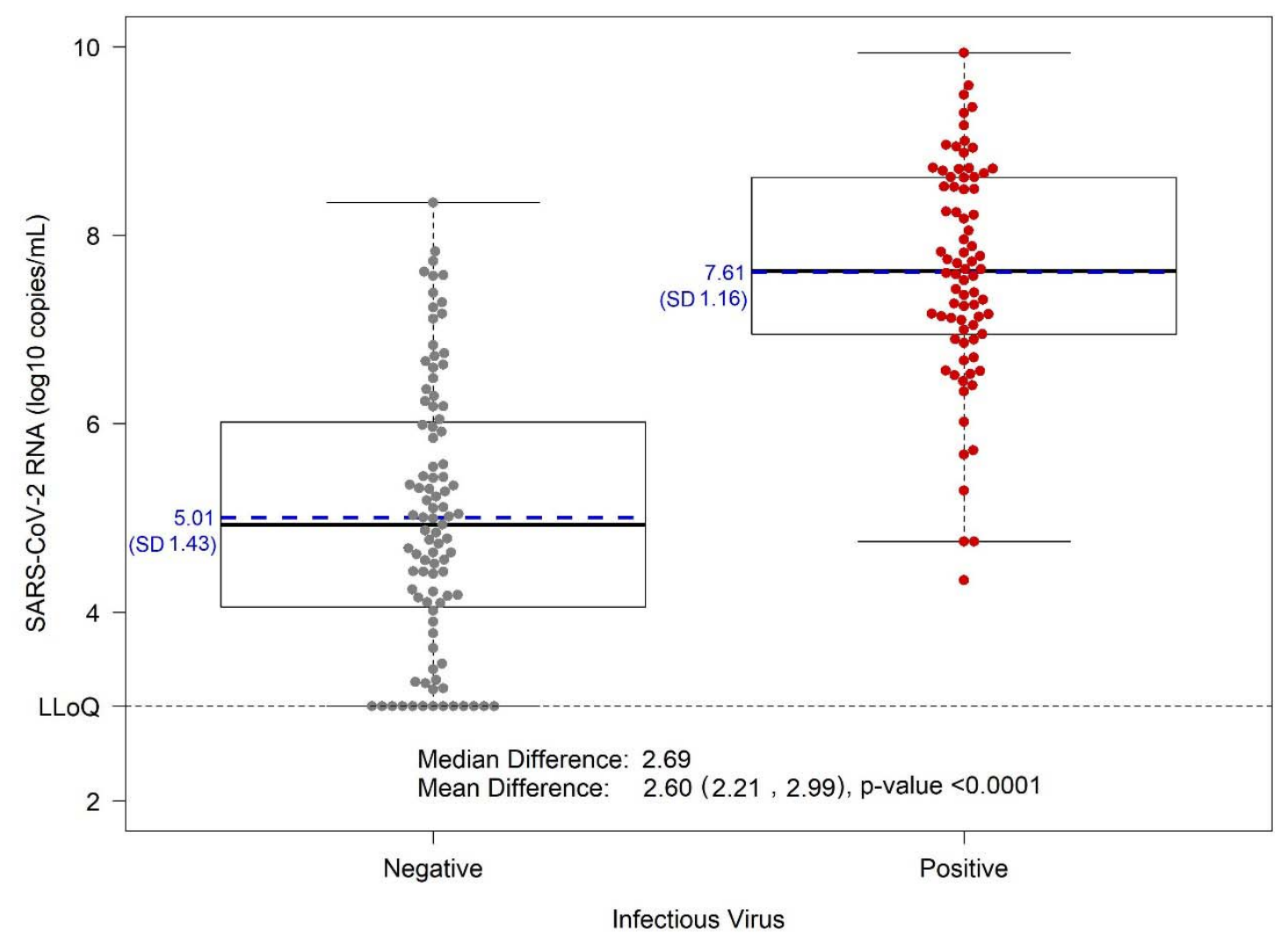




\section{Figure 2. SARS-CoV-2 viral RNA, time since symptom onset, and infectious virus by SARS-CoV-2 specific antibody serostatus}

Panel A shows seropositive participants. Panel B shows seronegative participants. Seropositive is defined as having SARS-CoV-2 specific total Ig, IgG, IgM, or IgA antibodies. Nasopharyngeal viral RNA levels $\left(\log _{10} \operatorname{copies} / \mathrm{mL}\right)$ are shown on the y-axis and days since symptom onset on the $\mathrm{x}$ axis, with infectious virus culture positive participants in red circles, and culture negative participants in grey squares. The overall viral RNA median $(\mathrm{Q} 1, \mathrm{Q} 3)$ and LLoQ are indicated by dashed horizontal lines. Ig $=$ immunoglobulin; LLoQ $=$ lower limit of quantification; $\mathrm{Q} 1=25^{\text {th }}$ percentile; $\mathrm{Q} 3=75^{\text {th }}$ percentile.
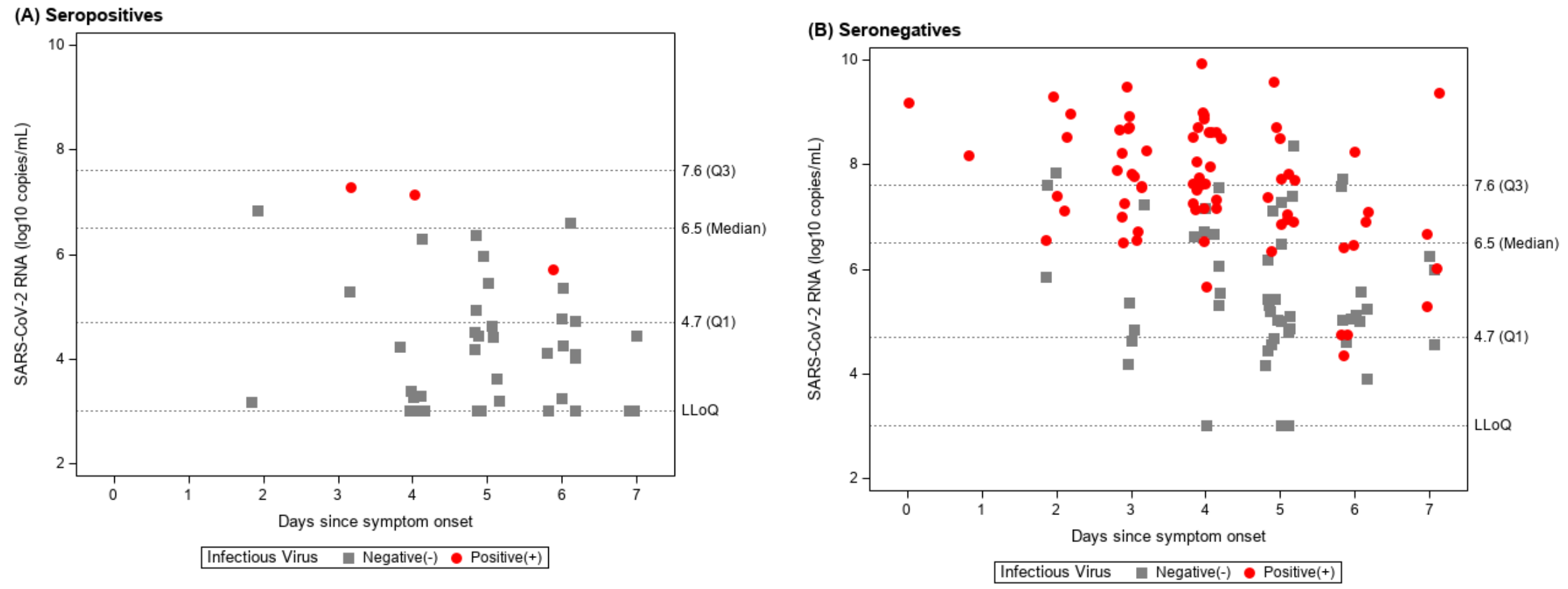


\section{Figure 3. Host factor associations with infectious SARS-CoV-2 virus isolation}

Bivariate unadjusted analyses are shown. *Prevalence ratios for the probability of infectious virus isolation were estimated for each dichotomous characteristic and a prevalence ratio per unit change was estimated for each continuous characteristic with corresponding $95 \%$ confidence intervals. Each continuous characteristic was fit as linear in the log-prevalence of infectious virus isolation. PR $=$ prevalence ratio.

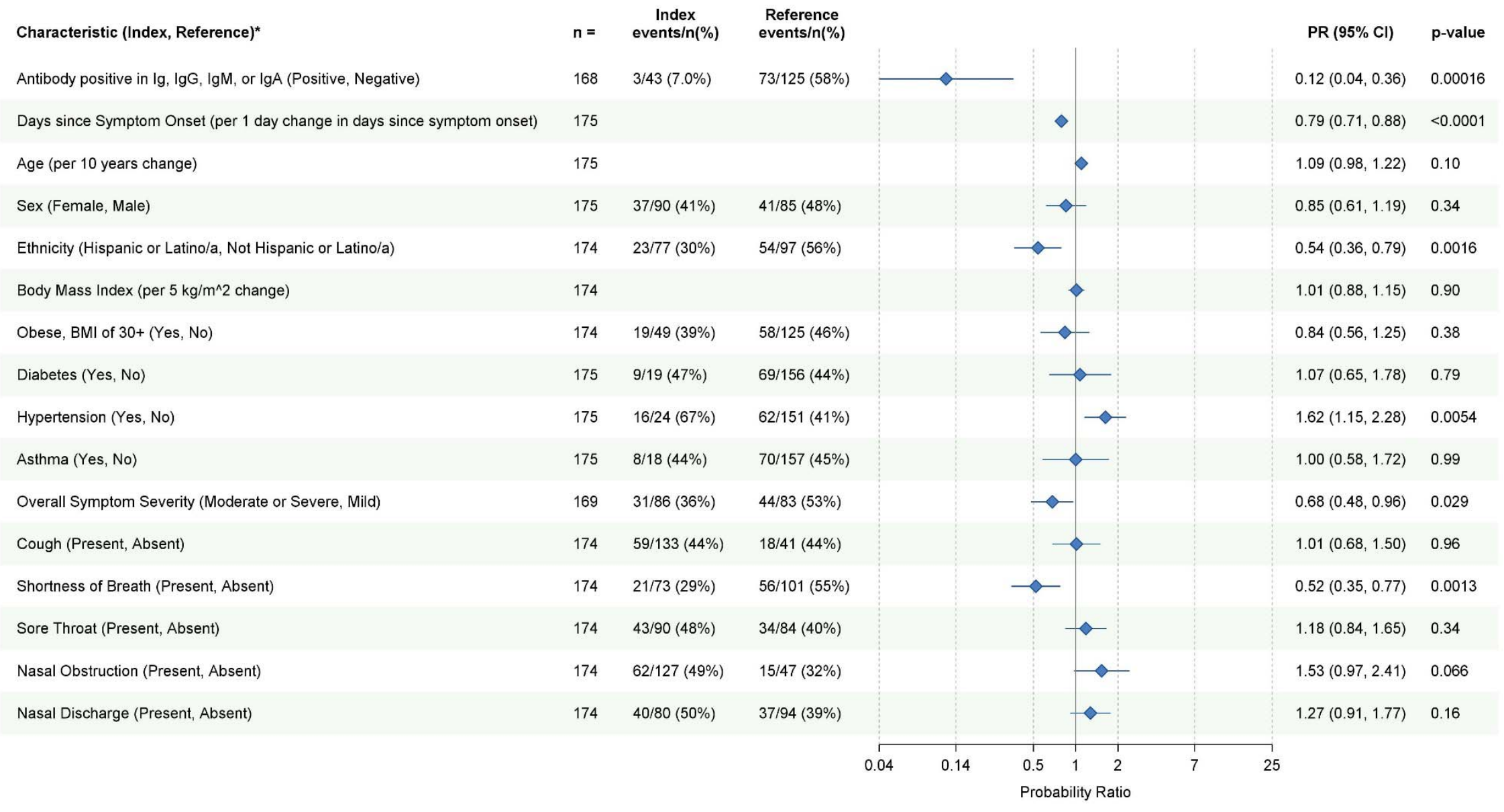




\section{Supplementary Figure 1. SARS-CoV-2 virus isolation, viral RNA, and serostatus according to days since symptom onset}

Estimated prevalence of antibody positive (teal), prevalence of infectious virus positive (red), and the median viral RNA level (orange) are shown according to day since symptom onset. The left y-axis corresponds to viral RNA level and the right y-axis shows both the prevalence of infectious virus and prevalence of antibody positivity. Trend lines were estimated using a quadratic fit.

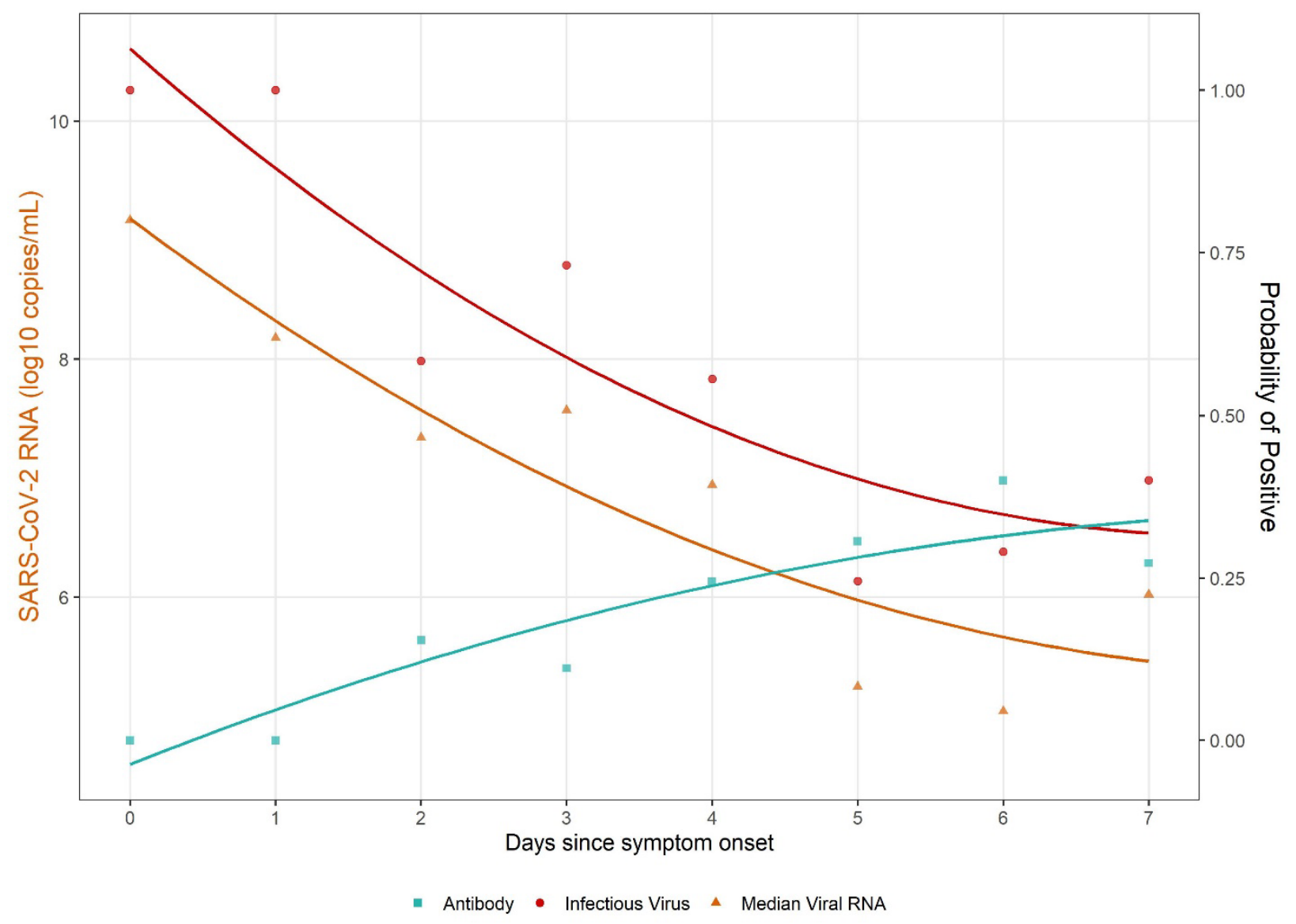




\section{Supplementary Figure 2. Associations between hematology measures and SARS-CoV-2 specific antibody status}

Panels A-E: Five hematology measures are displayed by SARS-CoV-2-specific antibody status (total Ig, IgG, IgM, or IgA positivity), with antibody negative shown in grey and antibody positive shown in teal; each dot represents a participant. Solid lines on boxplots display the median and 25th-75th percentile (mean = blue dashed line).
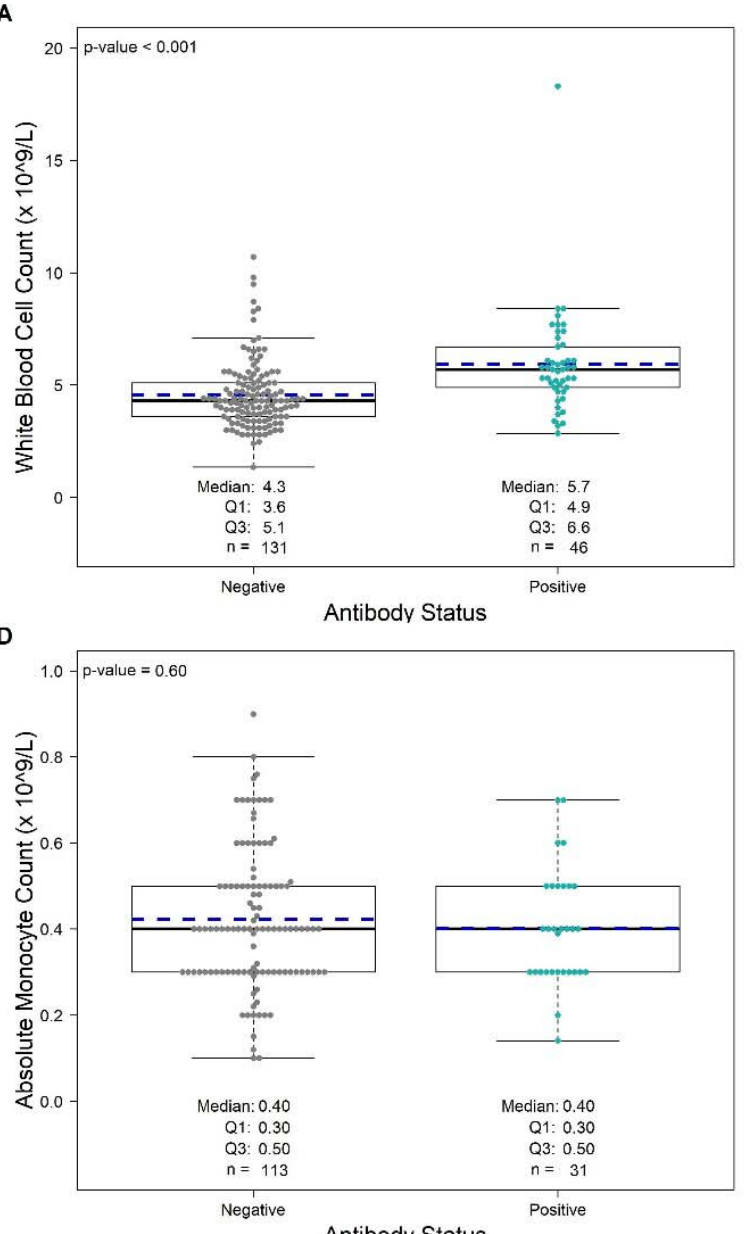
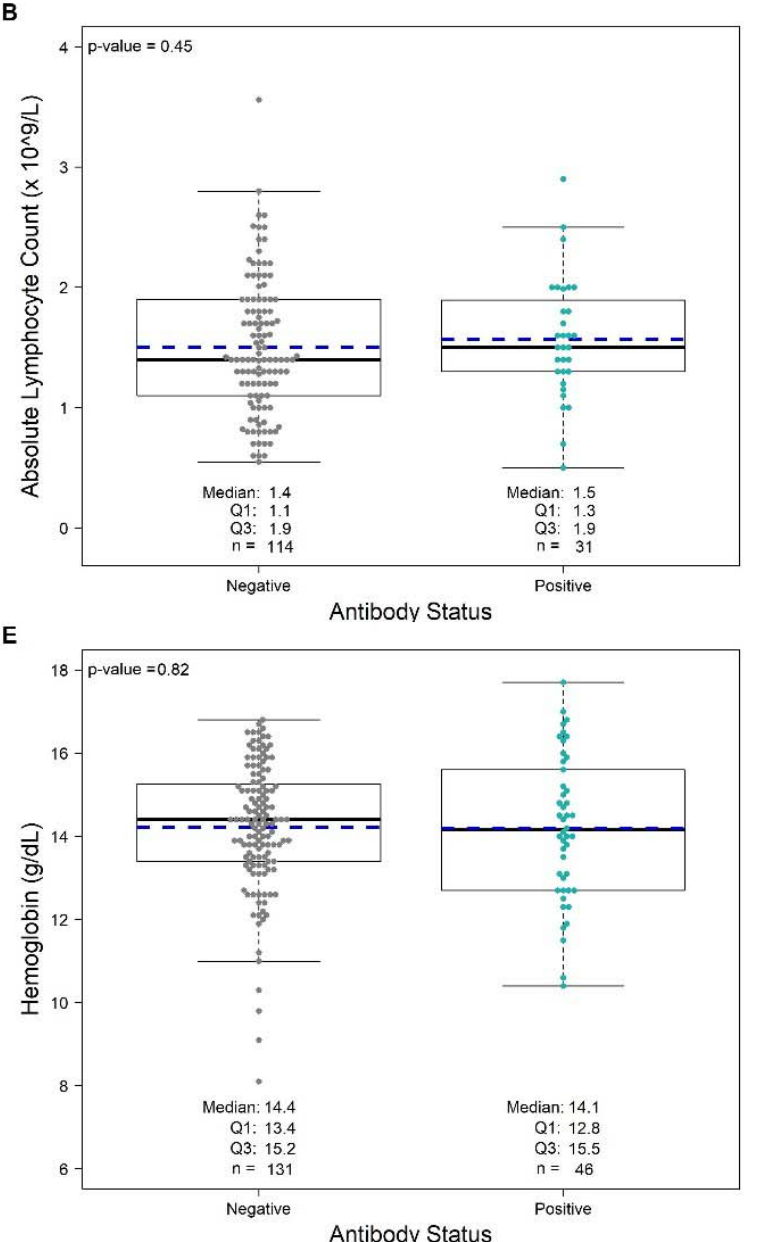

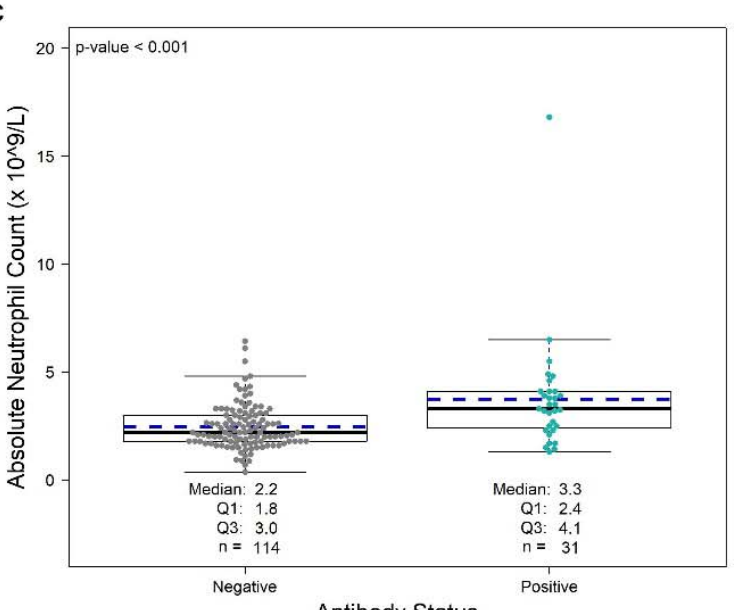

Antibody Status 


\section{Supplementary Figure 3. SARS-CoV-2 viral RNA by infectious virus culture - ROC Curve}

Panel A shows boxplots of viral RNA measured via qRT-PCR displayed by infectious virus status, with culture negative in grey and culture positive in red; each dot represents a participant. Panel B shows a receiver operator characteristic (ROC) curve. A threshold of 6.4 viral RNA log 10 copies/mL maximized sensitivity and specificity for SARS-CoV-2 infectious virus isolation and is represented by the green line on the boxplots and the corresponding green dot on the ROC curve.

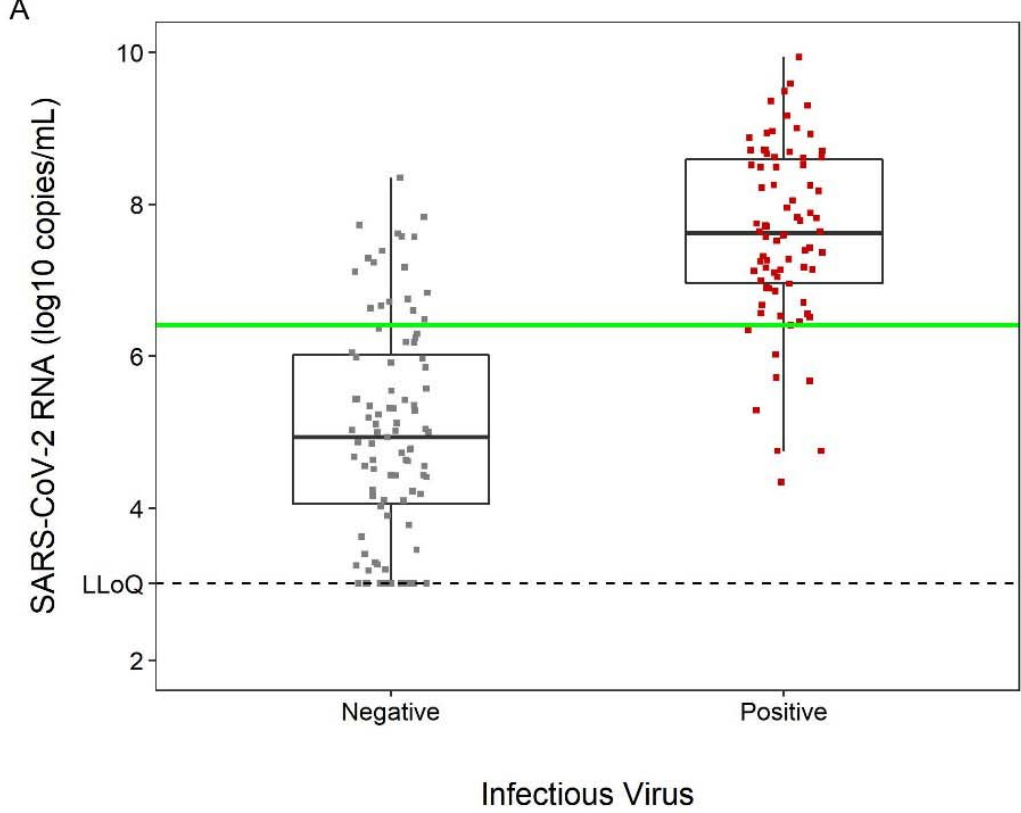

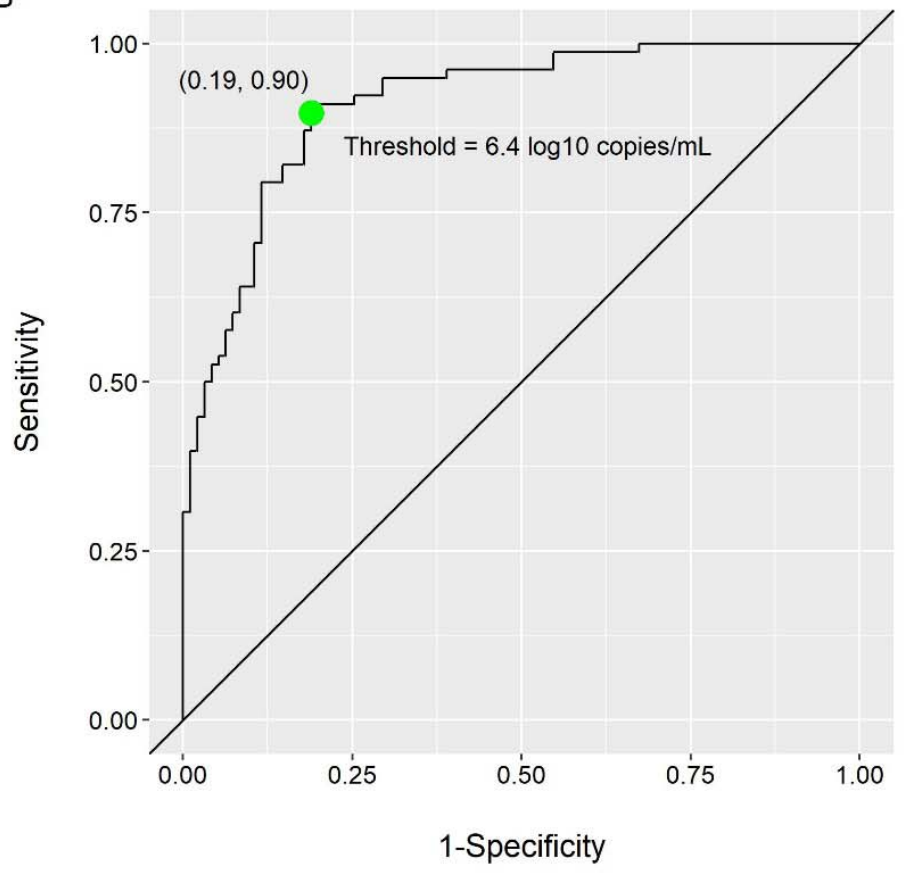




\section{Supplementary Figure 4. Associations between hematology measures and infectious SARS-CoV-2 virus}

Panels A-E: Five hematology measures are displayed by infectious virus status, with infectious virus culture negative shown in grey and culture positive shown in red; each dot represents a participant. Solid lines on boxplots display the median and 25 th-75th percentile (mean $=$ blue dashed line).
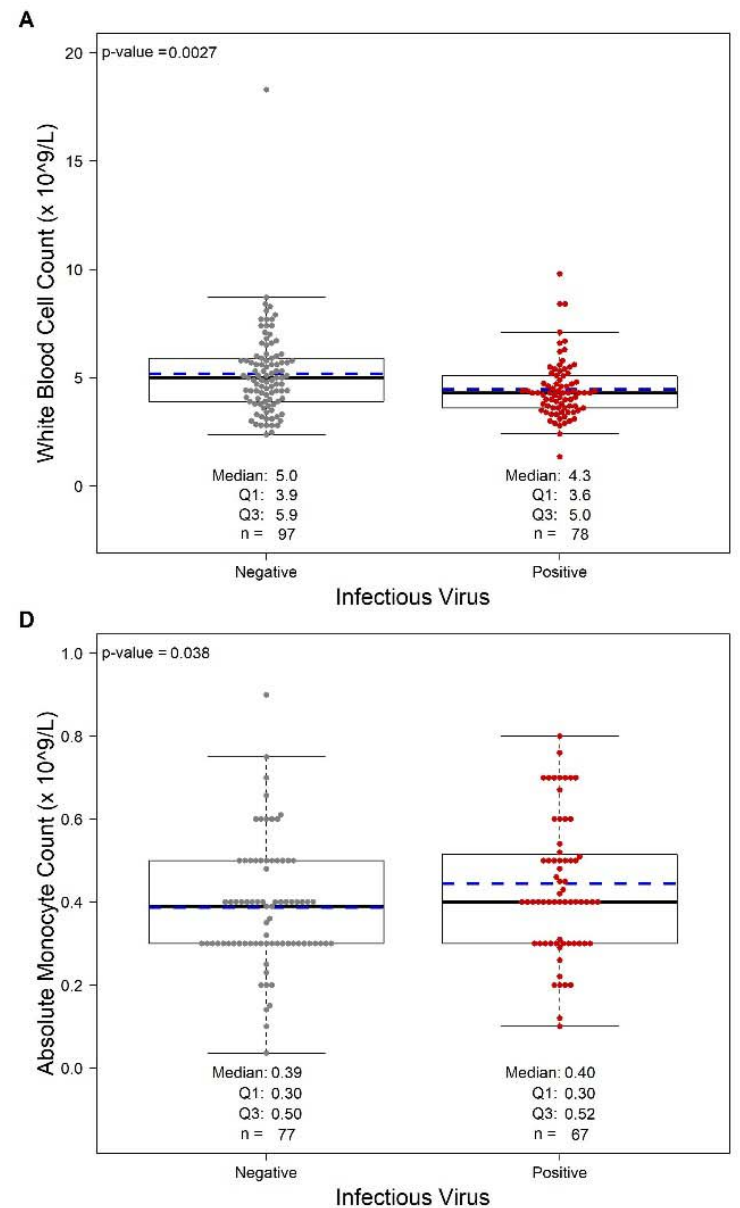

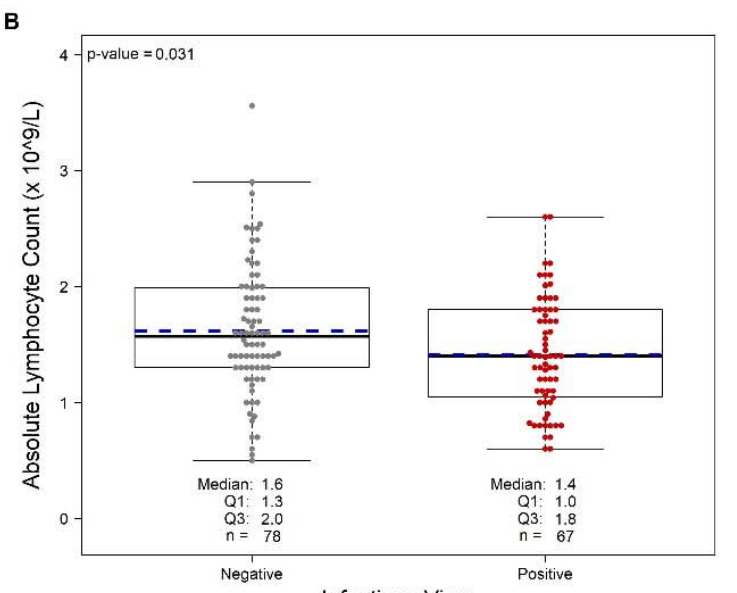

E

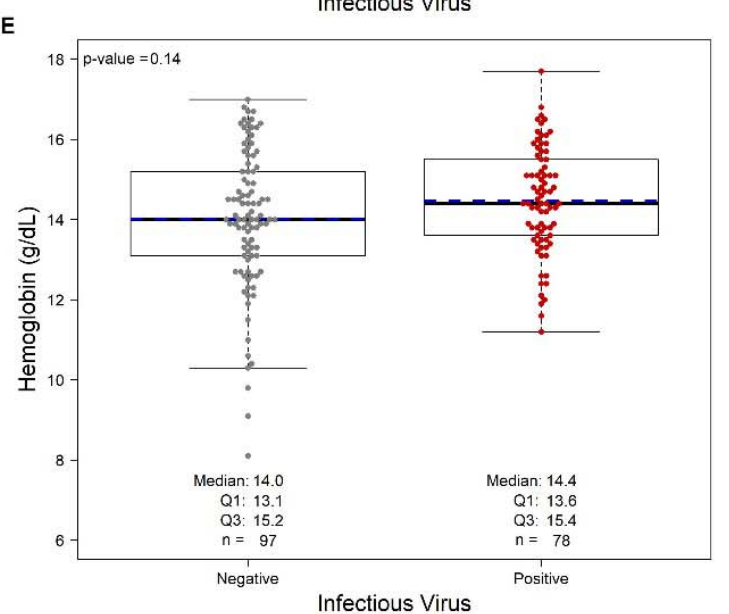

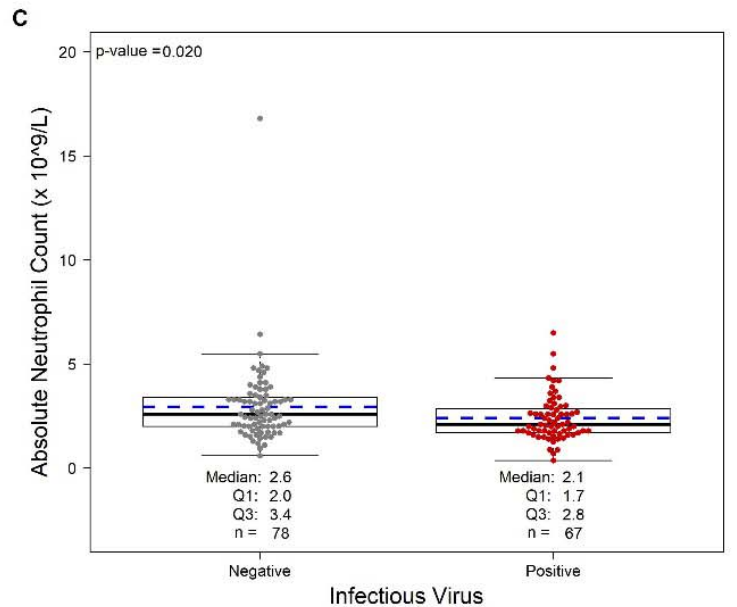

Infectious Virus 


\section{Supplementary Figure 5. Host factor associations with SARS-CoV-2 viral RNA level}

Bivariate analyses are shown. Mean differences in SARS-CoV-2 viral RNA $\left(\log _{10}\right.$ copies/mL) measured via qRT-PCR were estimated with a corresponding $95 \%$ confidence interval. $\mathrm{MD}=$ mean difference.

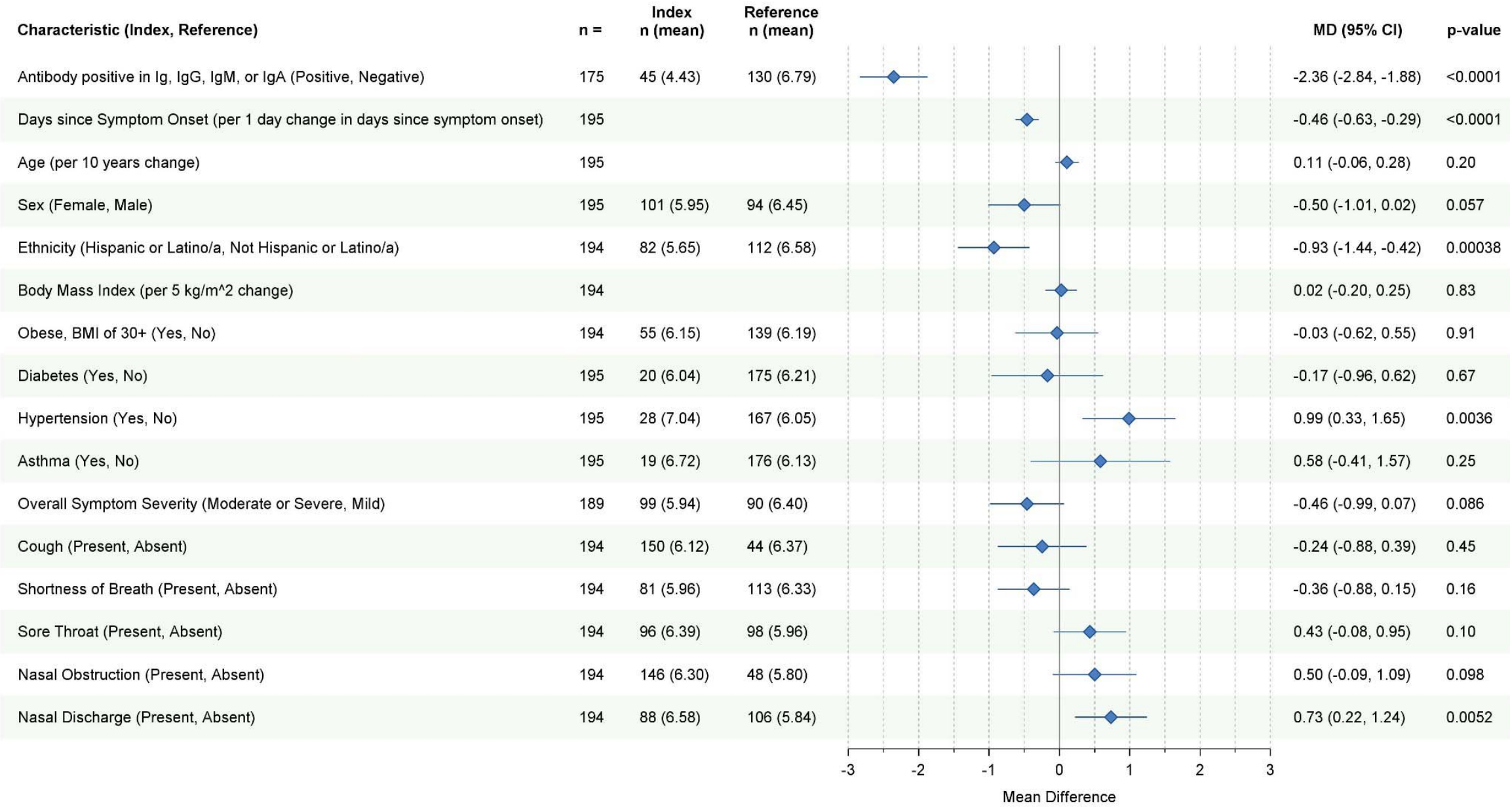

